\title{
GUIDE TO THE INTERNATIONAL ARCHIVES AND COLLECTIONS AT THE IISH: NEW EDITION IN 1999
}

The "Guide to the International Archives and Collections at the IISH, Amsterdam" (GIA), edited by Atie van der Horst and Elly Koen, was first published in 1989. Since 1990, a description of recently acquired archives and collections as well as major accruals to archives received by the IISH has been published annually in the IRSH to keep this survey up to date. From 1994 on, a list of microfilms of archives or collections held in other repositories, of which the IISH has received a copy, was added to this survey.

In September 1999, a new edition of the GIA will be published by the IISH. The recently acquired archives and collections as well as major accruals to archives received by the IISH over 1998 are included in this new edition. Therefore, no GIA supplement over 1998 is published in this volume.

Information on this new GIA edition can be obtained from Stichting beheer IISG, Cruquiusweg 3I, IOI9 AT Amsterdam, The Netherlands; tel: + 31 2066858 66; fax: + 31 2066564 II; e-mail: st.beheer@iisg.nl. 